ISSN 2519-2523 (print) Chornomors'ka mynuvshyna. -2019. - No.14.

DOI: $10.18524 / 2519-2523.2019 .14 .187123$

УДК 94(477)

\title{
HISTORICAL AND GEOGRAPHICAL ASPECTS OF RESEARCH THE PAST OF CHERNOMORIAN AND KUBAN COSSACKS (matters of cartographic reconstruction)
}

\author{
Anatoly Avramenko \\ ORCID: https://orcid.org/0000-0003-2538-7195 \\ Ph.D (History), Associate Professor, \\ Head of the Scientific Center of the Krasnodar Regional Public Organization \\ "Commonwealth of Kuban - Ukraine" \\ 12/A, Klubnaja Str., Krasnodar, 350051, Russia \\ shron2011a@gmail.com
}

The article explores the geographical aspects of the history of the Chernomorian and Kuban Cossacks and their display by means of historical cartography. There are examples of errors occurring due to the researchers' inability to use methods of historical geography and cartography are given. The author draws attention to the mistakes of some Ukrainian historical atlases and Russian publications. The article contains samples of author's maps, which allowed to raise to a new level the study of administrative-territorial division, geography and topography of the settlements of the Kuban region, the Holodomor of 1932-1933 and some other problems of regional history.

Key words: historical cartography, historical geography, Kuban region, Chernomorian Cossacks, Kuban Cossacks, historical and cartographic reconstruction.

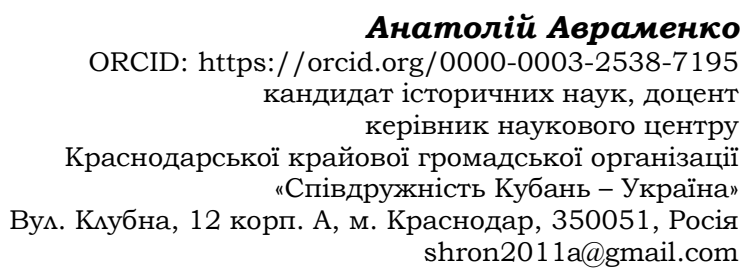

\section{ІСТОРИКО-ГЕОГРАФІЧНІ АСПЕКТИ ДОСАІДЖЕННЯ ЧОРНОМОРСЬКОЇ І КУБАНСЬКОЇ КОЗАЦЬКОЇ МИНУВШИНИ (питання картографічної реконструкціi)}

У статті досліджуються географічні аспекти історії чорноморського $i$ кубансъкого козаитва $і$ їх відображення засобами історичної картографіі. Наведені приклади помилок, шо відбуваються від не вірного використовування методів історичної географії та картографії. Звернуто увагу на помилки деяких украӥнських історичних атласів $і$ російсъких публікаиій. Стаття містить зразки авторських карт, ио дозволили підняти на новий рівень вивчення адміністративно-територіального поділу, географії та топографії населених пунктів Кубані та деяких інших проблем регіональної історії. 
Ключові слова: історична картографія, історична географія, Кубань, Чорноморсъке козаиьке війсъко, Кубанське козаиьке військо, історикокартографічна

Кубань - найбільша територія серед втрачених українських етнічних

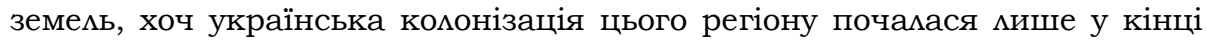
XVIII ст. Українські дослідники мають дуже фрагментарне уявлення про історію Кубані, що відображається на якості історичних карт [5]. 3 одного боку це можна пояснити відсутністю великої кількості наукової мітератури, що друкується зараз у Росії (так само російські дослідники мають примітивне уявлення про стан сучасної української історіографії). С початком російської агресії 2014 року стан речей тільки погіршився наукові стосунки вкрай обмежені, потрібні закордонні публікації бібліотеки отримують мише випадково. 3 іншого боку, багато аспектів кубанської історії, зокрема питання картографічної реконструкції чорноморської і кубанської козацької минувшини залишається невирішеними.

Якщо серед вчених України наукова комунікація не викликає великих перешкод, що сприяє своєчасному розповсюдженню інформації, між російськими істориками зростає "науковий феодалізм" - регіональні вчені добре знають своє середовище, місцевих цідерів, провідних

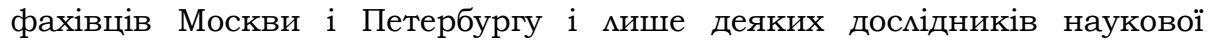
периферії. Нещодавно автор статті почув від керівника групи історичної географії Центру вивчення історії території та населення Росії Інституту російської історії РАН К. О. Авер'янова цікаву думку про те, що справжня наука зараз у Росії $є$ тільки у Москві. Звичайно, він мав на увазі історичну науку, але навіть це викликає сумнів. Концентрація друкованих джерел у найбільших бібліотеках, архівах і музеях, звичайно, дає чималі переваги мешканцям Москви і Петербургу. В умовах відсутності фінансування науки і шалених витрат у столиці провінційні дослідники можуть інколи дозволити собі мише короткочасні набіги на архіви, що може бути тільки імітацією науки. Проте столичні вчені теж не можуть дозволити собі тривалу роботу в провінційних архівах. Тому під керівництвом столичної наукової еліти складаються тимчасові колективи авторів, які працюють в стислий термін, щоб виконати умови гранту. Обговорювати твір, що йде до другу, немає часу. Саме така практика дає хибні результати, коли книга, видана у столиці викликає обурення в регіонах, яким вона присвячена.

У 2007 р. таким чином була створена колективна монографія, присвячена Північному Кавказу у складі Російської імперії [36]. Дев’ять авторів, на чолі з відомими московськими вченими В. О. Бобровніковим i I. $\Lambda$. Бабич, демонструють у цій книзі, що вони не знають безліч регіональних публікацій, а також важливих джерел. Саме тому тут повторюються помилки з дореволюційного Енциклопедичного словника Брокгауза і Ефрона. Зокрема, книга стверджує, що князь Потьомкін дав дозвіл "бывшим запорожцам Апрону Головатому, Хорьку Черепеге и Аегкоступу" (с. 76) збирати козаків у 1783 р. На Кубані навіть школярі знають Антона Головатого і Захарія Чепігу (Чепегу), але не згаданих 
"Апрона" i "Хорька" з вигаданим прізвищем. Так само, у книзі помилково стверджується, що Єкатеринодар був заснований у 1794 р., хоч насправді це відбулося у 1793 р. Уявлення авторів колективної монографії про адміністративно-територіальний устрій Північного Кавказу також не витримують критики.

Багато подібних помимок демонструють хибні історико-географічні уявлення авторів. Саме тому ще у 1997 р. в Армавірі за ініціативою професора В. Б. Виноградова була надрукована програма курсу історичної географії Краснодарського краю та Адигеї дмя шкіц, гімназій та Аіцеїв [1]. Дивмячись на те, що того ж року на замовмення крайового Департаменту освіти і науки був створений атмас "История Кубани. Краснодарский край. Республика Адыгея" [22], можна було сподіватися, що регіональні історико-географічні дослідження матимуть належну підтримку і досягнуть високого рівня (тим більше, що цей атлас містить безліч помилок, які треба було виправляти). Але цього не відбулося. Адміністрацію губернатора О. Ткачова (2001-2015 рр.) цілком влаштовували сурогати типу "Атамані" [40] та спорудження монументів, а реальні наукові проекти інтересу не викликали. Тому на вихід у Краснодарі першого спеціального історико-географічного збірника [21] не звернули увагу, хоча в той час навіть у Москві та Петербурзі подібних видань не було. Спроби закликати до підтримки розробки регіональних історичних атмасів [3; 4; 11] успіху не мали - чиновники вперто не хочуть фінансувати науку.

Важливість історико-географічного дослідження козацької минувшини не підлягає сумніву. Дивлячись на сучасні контури морських берегів, водосховища та меліоративні споруди неможливо уявити справжні маршрути походів та місця інших подій без історикокартографічної реконструкції. Сучасному читачеві важко зрозуміти, що у кінці XVIII ст., коли чорноморські козаки прийшли на Кубань, був "острів Таман", а не Таманський півострів, що головне гирло Кубані упадало в Чорне море, а не в Азовське. Виявляється, що без картографічної реконструкції адміністративного подіяу неможливо порівнювати статистичні джерела [2].

Перша проблема дослідника - отримати адекватне уявлення про фізико-географічне середовище певного історичного часу. Деякі спроби біолога і геоеколога С. А. Аитвинської дослідити зміни клімату і мандшафту регіону [27] не супроводжуються відповідними картографічними реконструкціями, а тому не можуть бути основою дмя вивчення змін берегової смуги Азовського моря чи русел річок. До початку XIX ст. маємо цише приблизне уявлення також про горно-лісові мандшафти Закубання.

Існуючі картографічні джерела для Чорноморії (Землі Чорноморського козацького війська) можуть вважатися переконливими тільки з кінця 50-років XIX ст., коли Межова комісія закінчила топографічну зйомку цієї території у масштабі 200 сажнів у дюймі [Докладніше див.: 7]. На підставі 407 планшетів цієї зйомки були створені і надруковані карти Чорноморії у масштабі 10 і 20 верст у дюймі [34, № 21205]. Aле 
вони досі залишаються майже невідомими дослідникам. Остання карта була надрукована Іваном Попкою у 1858 р., як додаток до його книги [30]. На жаль, коли видавництво “Советская Кубань" у 1998 р. передрукувало цю книгу, карту вирішили скоротити. Редакція пояснила це у примітці: «Ввиду того, что карта Черномории 1857 г., помещенная в книге, дошла до нас в крайне ветхом состоянии, воспроизвести ее оказалось невозможным" [31, с. 9]. Насправді ініціатори видання не зверталися до фахівців за консультацією і тому не знали, що згадані карти у Військово-історичному архіві збереглися в ідеальному стані і можна бумо зробити копію там. До речі, пізніше московське видавництво "Вече", добре відоме вемикими спотвореннями оригіналів, зАіпимо дві книги (І. Попки і П. Короменка) в одну і надрукувало карту Чорноморії з книги Попки, але дуже неякісно - зменшивши її до абсурду [43].

Звичайно, постає питання, як зробити реконструкцію природного середовища з кінця XVI ст., коли починається козацька доба у регіоні. 3 того часу дуже змінилися русла річок і єриків, зникли деякі озера та мимани, в деяких місцях радикально змінилися берегові контури. Через це, наприклад, дискусійним вважається місце розгрому турками донської козацької ффотимії у 1638 р. Найбільш переконливу точку зору обгрунтували історики В. М. Корольов та І. В. Волков [24; 18], згідно якій це відбулося в районі сучасного Таманського півострова, а I. Волков зробив цікаву картографічну реконструкцію події.

Найбімьш скмадною є гіпотетична реконструкція ймовірних берегів Азовського моря різних часів. Деякі спроби робив, єйський географ Ю.В. Артюхін [12-15], але подібна робота потребує чималого фінансування комплексних досліджень археологічних, гідрологічних, геологічних тощо. Звичайно, державне фінансування цього проекту в сучасних умовах неможииве.

Карти Землі Війська Чорноморського кінця XVIII ст., що збереглися у Військово-історичному архіві у Москві [34, № 20483], дозволяють побачити природне середовище, у якому опинилися козаки в перші роки після переселення на Прикубанські землі. На підставі цих джерец, а також матеріалів перепису 1793-1794 гг. [6] була створена карта [Див. додаток 1], що демонструє цікаве становище: військо ще тільки починає розміщуватися на території між річками Кубань і Єя, деякі курені i курінні отамани вже були у Єкатеринодарі (саме так називає місто "Енциклопедія історії України" [20, т. 3, с. 116; т. 5, с. 297-298]), деякі ще залишалися у Тамані чи поруч з нею, з'явилися поселення (слободи), які незабаром були перейменовані і отримали назви куренів колишнього Війська Запорозького, які відновилися у Війську Чорноморському, рибні "заводи" козацької старшини, перші кордони Чорноморської мінії. Відомо, що на території між Південним Бугом і Дністром чорноморці почали створювати адміністративний поділ на паланки, що існував раніше у Війську Запорозькому, але з новими назвами: Подністрянську, Березанську і Кінбурнську [25, с. 56]. Цікаво, що чорноморці на Кубані спочатку теж почали формувати 3 паланки: Єйську, Копимьську і Єкатеринодарську. Але вже "Порядок общей помьзы", розроблений керів- 
никами козацького війська (З. Чепігою, А. Головатим і Т. Котляревським) і прийнятий 1 січня 1794 р. встановив новий поділ на 5 округів: Єкатеринодарський, Фанагорійський, Бейсузький, Єйський і Григор'євський.

Згідно своїм звичкам козаки почали утворювати численні хутори по річках (тільки деякі можливо мокалізувати), сіромахи розбрідалися по різних місцях (зимівниках, рибних заводах тощо), де можна було харчуватися. Козаків майже кожного куреня, як виявив перепис, можна було знайти по всій Чорноморії, внаслідок чого дуже важко було курінним отаманам збирати козаків дмя кордонної чи іншої смужби. Як писав $\Phi$. А. Щербина, "Черноморцы явно вышли из повиновения начальству и вели себя наперекор распоряжениям войскового правительства" [45, c. 554]. Саме тому було вирішено на карті визначити місця для утворення курінних поселень, куди повинні були переселитися козаки відповідного куреня, за жеребом.

Як виявив кубанський краєзнавець В. О. Соловйов, дмя козаків, які не мали сімей і навіть майна (сіромахи), у Єкатеринодарській фортеці були побудовані 8 дерев'яних касерень, кожна 3 яких поділялася на 5 частин, таким чином розмістили 40 куренів [39, с. 21-23]. На відміну від Січі, ці побудови (курені) у Єкатеринодарі були розташовані квадратом, у середині якого незабаром звели великий дерев'яний військовий собор. В цих самих куренях-касарнях жили курінні отамани (до 1802 р.) [25, с. 68], а також козаки відповідного куреня під час відрядження в Єкатеринодар. Дерев'яні побудови швидко занепали, тому протягом 1810-1817 рр. були створені нові курені з цегли, позначені на плані Соловйова [39, с. 28]. Розташування куренів у фор-

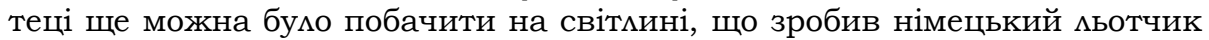
у 1941 р. під час війни [Див. додаток 3], але вже набагато пізніше, коли треба було звернути увагу на збереження історичної спадщини, це все було знищено.

Важливо звернути увагу на географію місць, призначених для поселень чорноморських козаків. Відносно безпечним було розташування на півночі Чорноморії (Щербинівське, Дерев'янківське, Менське, Конеловське, Шкуринське, Кущовське, Кисляковське, Переясловське, Уманське, Скатериновське, Незамаєвське, Калниболотське, Криловське курінні поселення). Частина куренів була розташована уздовж східної межі Чорноморії, щоб закріпили ці землі за військом (Калниболотське, Криловське, Аеушковське, Іркліївське, Брюховецьке, Березанське, Батуринське, Кореновське, Дядьківське, Пматнирівське, Сергіївське курінні поселення). Вкрай небезпечним було розташування уздовж р. Кубані на кордонній мінії (Васюринське, Корсунське, Пмастуновське, Дінське, Пашковське, Величковське, Тимошевське, Роговське, Поповичівське, Мишастовське, Івановське, яке спочатку йменувалося Івонівським, Нижчестебліївське, Полтавське, Джереліївське, Канівське, Ведмедівське, Титарівське, Вищестебліївське). Саме тут поселенці частіше гинули як він нападів черкесів, так і від страшних хвороб. Невдале первісне розташування курінних поселень призвело незабаром до низки переміщень на нові місця. 
Протягом 1994 р. всі кубанські станиці, назви яких походять від перших чорноморських куренів, відсвяткували своє 200-річчя. Насправді цей ювілей для багатьох з них ще попереду. Зокрема, Дінське курінне поселення, засноване у 1794 р. біля Пцастуновського на березі Кубані, разом з ним було переселене 1814 р. на р. Кочети, а у 1827 р. вони були об'єднані (Дінське увійшло до складу Пластуновського). Тоді ж керівництво Війська Чорноморського перейменувало поселення, засноване 1822 року переселенцями з Аівобережної України, на Дінське [44, c. 143], щоб зберегти стару курінну назву, тому що розуміло - це частина культурної спадщини. Тому сучасна станиця Дінська не має генетичного зв'язку з однойменним курінним поселенням, заснованим у 1794 p. i свій 200-річний ювілей має святкувати у 2022 р. [див.: 10].

Насправді проблема географії козацьких поселень на Кубані ще більш складна, бо потребує вивчення місць розташування некрасовців та інших козаків-старовірів, які з'явилися тут у кінці XVII - на початку XVIII ст. у володіннях Кримського ханату. Дещо в цьому відношенні зробив колишній краснодарський, а нині ростовський історик Д. Сень [37; 38]. Проте в його дослідженнях бракує саме картографічної реконструкції географії поселень.

Одною 3 важливих проблем історичної картографії Кубані $\epsilon$ реконструкція змін в етнічній географії. Абсолютна більшість сучасних кубанських істориків і етнологів з політичних причин намагається не помічати українського фактору з середини XIX ст., а директор Науководослідного центру традиційної культури Кубанського козачого хору професор М. І. Бондар насаджує хибну теорію, згідно якій на початку ХX ст. у Кубанській області склався єдиний субетнос "кубанське козацтво", що відірвався від українського народу. Ця теорія ретельно розкритикована у працях Н. О. Супрун-Яремко i В. К. Чумаченка [Докладніше див.: 8], проте етапи змін в етнічній ідентичності треба вивчати майбутнім дослідникам. Якщо українські атласи об'єктивно відображують етногеографію Кубані [42, с. 3, 10-12, 15, 23; 17, с. 73, 91; та ін.] за статистичними джерелами, в аналогічних російських публікаціях намагаються уникати цієї тематики, якщо треба зазначити рідну мову населення регіону.

Дуже складним є питання адміністративно-територіального поділу земель чорноморських і кубанських козаків. До 1870 р., коли почалося розмежування станичних юртових земель, адміністративні окружні межі можна було уявили мише приблизно - між станицями у середині століття були постійні свари за землю. Тому не відповідають дійсності межі округів Чорноморії, позначені на карті Ю.І. Аози «Землі Чорноморського козацького війська (1792-1860 рр.)" [41, с. 19] - автор використав для їх реконструкції межі станичних юртів, що з'явилися пізніше внаслідок розмежування. Та ж помилка механічно перейшла в атлас "Інституту передових технологій" $[16$, с. 11], де були використані матеріали Ю.І. Аози без посимання на джерело.

Навіть кубанські історики мише в останні роки почали приділяти увагу складному питанню адміністративно-територіального поділу регіо- 
ну. Зазвичай писали, що в 1870 р. Кубанська область була розподілена на 5 уєздов (повітів), а незабаром було створено ще два - Закубанський і Кавказький. У 1888 р. замість повітів створили 7 однойменних відділів і деякі дослідники досі вважають, що йдеться тільки про перейменування.

Коли на замовлення крайового управління МВС Краснодарського краю місцевими істориками були написані нариси історії до революційної кубанської поліції, автор статті отримав завдання створити 3 карти [29]. Під час роботи було виявлено стільки змін адміністративного подіку, що треба було звертати увагу мише на головне [Див. додатки 57], бо потрібен був цілий атлас. Десятиліття 1860-1870 pp. взагалі прийшлося скоротити. Навіть в такому вигляді карти були місцевою сенсацією - вони переконливо доводили, що радикальні зміни територій адміністративних одиниць дуже впливали на якість статистики. Багато інформації дослідники не могли знайти, бо не мали правильного уявлення про знаходження поселення в певному відділі або окрузі. В деякий час військовий поділ Кубанського козацького війська на 3 відділи дуже відрізнявся від цивільного поділу на 7 повітів, свій окремий адміністративно-територіальний поділ мала церква (єпархія, благочиння), судові, податкові та інші установи.

Виявилося, що у Кавказькому мінійному козацькому війську (6 бригад його правого крила у 1860 р. разом із Чорноморським військом об'єднали в штучне Кубанське військо): багато станиць не мали відношення до Ставропольської губернії, в свою чергу велика частина цієї губернії знаходицася за межами війська. 3 часу створення Кубанського козацького війська до 1870 р. частина його станиць також знаходимася за межами Кубанської області (у Ставропольській губернії та Чорноморському окрузі). Зміни адміністративного подіяу відбувалися в регіоні майже щорічно. Зокрема конфігурація Кавказького віддіку 1891 року буда зовсім не схожою з територією віддіку 1917 року [Див. додаток 7]. Не має сумніву в тому, що треба створити докладний довідник з картами, але коштів на це немає.

Досі погано відображена на історичних картах участь чорноморських і кубанських козаків у війнах дореволюційної Росії, в подіях Громадянської та Другої світової війни (у складі РСЧА та Вермахту), соціальна історія козацтва, не кажучи вже про страшний Голодомор 1932-1933 рр. та знищення козацтва під час інших репресій. Російські політики і ЗМІ вперто заперечують антиукраїнську спрямованість Голодомору. Але відомо, що відсоток скорочення українського населення на Кубані набагато перевершує демографічні втрати інших народів. На "чорну дошку" потрапили наступні станиці Кубані, де населення зазнало особливо жорстокого знищення (інформація була надана авторові карти професором I. I. А^єксєєнком): Медвьодовська, Старощербиновська, Шкуринська, Кущовська, Кисляковська, Незамаєвська, Новопашковська, Новодерев'янковська, Стародерев'янковська, Уманська, Полтавська, Пцатнировська, Старокорсунська, Новорождєственська, Теміргоєвська, Усть-Цабінська, Урупська. Перші 13 з них - колишні чорно- 
морські станиці, де українське населення абсолютно переважало, 4 станиці - Аінійні, де українці складали чималий відсоток населення. Це вперше було відображено на карті А. Авраменка "Кубань и Причерноморье в 1920-1937 гг." в підручнику для студентів Краснодарського краю [23]. Але треба ще додати примусові депортації з метою зміни етнічного складу населення регіону.

Тільки з чотирьох великих станиць - Полтавської, Медвьодовської, Урупської та Уманської тоді було вивезено на Північ СРСР 51,6 тис. осіб (три 3 них - чорноморські станиці), а 3 решти (Гривенська, Пцастуновська, Пцатнировська, Старокорсунська, Старомишастовська) - не менше ніж 10 тисяч). Все перелічені станиці, крім Урупської, належали до колишньої Чорноморії, заселеної українцями [26, с. 312]. Некозацькі населені пункти Кубані взагалі уникли подібної долі. На місце знищених або виселених за межі регіону кубанців переселяли демобілізованих червоноармійців (до середини грудня 1933 року на Кубань "прибыло 105 эшелонов с общим числом переселенцев 38504 чел., из них мужчин 19499 чел., женщин - 11388 чел., детей - 7617 чел.» [33; 32, с. 342]). Одночасно здійснювалося переселення на Кубань цілих колгоспів 3 Ростовської області та Ставропольського краю [28, с. 27].

За спогадами I. $\Lambda$. Помежаєва, мешканця станиці Уманської, тільки приїзд переселенців урятував повне знищення станиці: "Станиця трошки ожила. Правда, тут головну роль грають тепер переселенці білоруси, народ міцний, надійний, працьовитий і симпатичний. Дмя станиці їхній приїзд рівносильний уливанню крові в організм умираючої цюдини, що його й рятує в остаточному підсумку. Своїми власними очами побачив я цю агонію. Бінь і жах у серці» [19, с. 57]. Саме $з$ того часу українська мова почала зникати в кубанських станицях.

Перелік тематики, що потребує історико-картографічного дослідження, можна продовжувати. Наприклад, взагалі немає карт кубанської козацької еміграції. Відродження кубанського козацтва кінця XX початку XXI ст. представлено мише одною картою [9]. А^е там інформація стосується тільки реєстрового Кубанського козацького війська, а на той час було ще два окремих козацьких війська на Кубані, що мали зовсім інші структури.

Цікавим аспектом проблеми є місцева топонімія. Це складний симбіоз тюркських, адигських, слов'янських та інших назв. Ангелінський єрик, що на деяких картах перетворився на "Англійський", раніше мав назву Єнгали, яка була спотворена козаками-переселенцями. Так само 3 перероблених татарських чи ногайських назв виникли найменування річок Кочети, Кірпілі, Єя, Челбас, Бейсуг, назви місцевих миманів, піщаних кос. Цікаве дослідження архівіста С. В. Самовтора відображає процеси козацької колонізації в топонімії Кубані [35].

Багато помилок в мітературі, що вважається науковою, можна пояснити тим, що дослідники не мають знань у галузі історичної географії та картографії. Принцип єдності часу і простору передбачає, що вивчати історію необхідно у зв'язку з дослідженням географічних аспектів історичного процесу. Проте "реформатори" сучасної вищої 
освіти в Росії вкрай скоротили і без того поверхове вивчення в університетах історичної географії (історична картографія взагалі не вивчається), що є наслідком нерозуміння пї важливої роли. Саме тому численні помилки у вивченні регіональної історії спотворюють загальну історію країни. Великою шкодою залишається розпорошеність дослідників і дослідницьких центрів. Крім того, немає повного обліку картографічних видань, що друкуються не тільки у світі, а навіть у Росії. Дуже багато "текстових карт" бібліографи навіть не відстежують і кожна 3 них може бути сенсацією дмя фахівців. Таке примітивне ставлення до історичної картографії треба негайно змінювати.

\section{Джерема та мітература:}

1. Авраменко А.М., Виноградов В.Б., Какуша О.Н. Историческая география Краснодарского края и Адыгеи (досоветский период): Программа (часть 1)

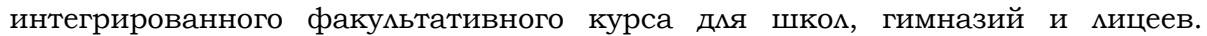
Армавир-Краснодар, 1997. 16 с.

2. Авраменко А.М. Нерешённые проблемы изучения административнотерриториального деления Северного Кавказа конца XVIII - начала XX в. // Северный Кавказ: геополитика, история, культура. Материалы всероссийской научной конференции (Ставрополь, 11-14 сентября 2001 г.). Ч. 1. Москва Ставрополь, 2001. С. 149-150.

3. Авраменко А.М. Атмас истории казачества: идея, концепция и структура // Казачество России: история и современность. Тезисы Международной научной конференции г. Геленджик (8-11 октября 2002 г.). Краснодар, 2002. С. 4-7.

4. Авраменко А.М. Подготовка "Кубанского исторического атласа": идея и предполагаемая структура // Освоение Кубани казачеством: Вопросы истории и культуры. Краснодар, 2002. С. 18-29.

5. Авраменко А.М. Історія Кубані в сучасних українських атласах // Історикогеографічні дослідження в Україні. Збірка наукових праць. Число 8. Київ, 2005. С. 255-265.

6. Авраменко А.М. Черноморское казачье войско по переписи 1793-1794 гг. [Карта]. // Первая перепись казаков-переселенцев на Кубань в конце XVIII века: Исторические документы. Краснодар: ООО "Диапазон-В», 2006. Вклейка после с. 464.

7. Авраменко А.М. Материалы Межевой комиссии Черноморского казачьего войска (1848-1860 гг.) как историко-географический источник // Историкогеографический сборник. Вып. 1. Краснодар: ООО "Картика», 2007. С. 374408.

8. Авраменко А. М. Третя збірка "Кубань - Україна" і деякі проблеми кубанської україністики // Кубань-Украина: вопросы историко-культурного взаимодействия. Вып. 3. Краснодар, 2008. С. 6-15.

9. Авраменко А. Кубанское казачье войско (по данным на 1 ноября 2010 г.) [карта] // Энциклопедия кубанского казачества / Под ред. В.Н. Ратушняка. Краснодар: Традиция, 2011. Цветная вклейка между с. 448/449.

10. Авраменко А. Зміни в географії населених пунктів Кубані, назви яких походять від запорозьких куренів (до проблеми збереження історикокультурної спадщини) // Записки Наукового товариства імені Шевченка. T. CCLXXI: Праці Комісії спеціальних (допоміжних) історичних дисципмін. Аьвів, 2018. С. 624-640. 
11. Авраменко А.М. Концепция Кубанского историко-культурного атласа как составной части программы изучения культурного наследия народов Северного Кавказа [Электронный ресурс] // Наследие веков. 2018. № 1. С. 5666. URL: http://heritage-magazine.com/wp-content/ uploads/2018/02/2018_1_ Avramenko.pdf (дата обращения 24.10.2019).

12. Артюхин Ю.В. Перестройка береговой зоны Азовского моря как фактор некоторых исторических событий XVIII-XX вв. // Историко-географический сборник. Вып. 1. Краснодар, 2007. С. 313-328.

13. Артюхин Ю.В., Родионова Н.Б. Историко-географические аспекты освоения Ейского мимана Азовского моря и эвоцюции населённых пунктов его побережья // Историко-географический сборник. Вып. 1. Краснодар, 2007. C. 329-340.

14. Артюхин Ю.В. Океанологический фон противоборства России и Турции за обладание устьевой частью р. Дон. // Бомьшой Ромбит. Сборник статей по истории и исторической географии Восточного Приазовья. Ейск, 2010. С. 1925.

15. Артюхин Ю.В. Климатический и океанолого-ландшафтный фон противоборства казачества и Османской империи в XVI-XVII вв. // Боспорские исследования. Вып. XXXII. 2016. С. 149-163.

16. Атлас з історії України (друга помовина XVIII - початок XX ст.). 9 клас. / Упоряд.: О.В. Гісем, Д.В. Ісаєв, О.О. Мартинюк. К.: ІПТ, 2006.

17. Атлас історії України; упор. Д. Ісаєв. К.: ДНВП "Картографія", 2012.

18. Волков И.В. Еще раз об Адахунском сражении казачьего фмота в 1638 г. // Древности Кубани. Вып. 16. Краснодар, 2000. С. 42-63.

19. Дневники Ивана Аазаревича Полежаева (30-е годы, ст-ца Уманская) // Родная Кубань (митературно-исторический журнал). Краснодар, 2002. № 3. С. 57 .

20. Енциклопедія історії України. Т.3. Е-Й. К., 2005; Т. 5. Кон - Кю. К., 2008.

21. Историко-географический сборник. Вып. 1. Краснодар, 2007. 482 с., карт.

22. История Кубани. Краснодарский край. Республика Адыгея. [Атмас]. М., Краснодар, 1997. 42 с.

23. История Кубани с древнейших времён до конца XX века: Учебник дмя высших учебных заведений / Руководитель авт. комлектива проф. В.Е. Щетнёв. Краснодар: ОИПЦ "Перспективы образования", 2004. Цветная картавклейка между с. 256-257.

24. Королев В.Н. Адахунское сражение // Известия высших учебных заведений. Северо-Кавказский регион. Обществ. науки. Ростов-на-Дону, 1993. № 1/2. С. 24 34.

25. Короленко П.П. Черноморцы. СПб., 1874.

26. Кульчицький С.В. Голодомор 1932-1933 pp. на Кубані // Кубань-Украина: вопросы историко-культурного взаимодействия. Вып. 3. Краснодар, 2008. С. 312324.

27. Аитвинская С.А. Историческая экология (региональный очерк): Учебное пособие. Краснодар, 1997. 214 с.

28. Население России в XX в.: В 3 т. Т. 1. М., 2000.

29. Очерки истории органов внутренних дем Кубани. 1793-1917. / Под ред. профессора В.Н. Ратушняка. Краснодар: ЭДВИ, 2002. Кольорові карти вкцейки (автор А. Авраменко): Административно-территориальное деление и полиция Прикубанских земель в 1794-1860 гг.; Административно-полицейское демение Кубанской области и Черноморского округа в 1870-1888 гг.; 
Административно-полицейское деление Кубанской области и Черноморской губернии в 1888-1917 гг.

30. Попка И. Черноморские козаки в их гражданском и воинском быту. Очерки края, общества, вооруженной силы и службы. В 2-х ч. и 17 рассказах. СПб.: Типография П.А.Кулиша, 1858. Вклейка в кінці книги.

31. Попка И.Д. Черноморские казаки в их гражданском и военном быту: Очерки края, общества, вооруженной силы и службы. В 2 ч. Краснодар: Сов. Кубань, 1998.

32. Ракачёв В. Н. Голод 1932-1933 гг. на Кубани и его демографические последствия // Кубань-Украина: вопросы историко-культурного взаимодействия. Вып. 3. Краснодар, 2008. С. 326-345.

33. Российский государственный архив экономики. Ф. 5675. Оп. 1. Д. 32. ヘ. 26.

34. Российский государственный военно-исторический архив. Ф. ВУА (Военноученый архив).

35. Самовтор С.В. Отражение процессов казачьей колонизации в топонимии Кубани (конец XVIII - начало XX вв.): Автореферат дисс. ... канд. ист. наук. Ставрополь, 2008.

36. Северный Кавказ в составе Российской империи. М., 2007. 460 с., иц., карт.

37. Сень Д.В. «Войско Кубанское Игнатово Кавказское»: исторические пути казаков-некрасовцев (1708 - конец 1920-х гг.). Краснодар, 2001. 385 с.; То же. 2-е изд., испр. и доп. Краснодар, 2002. 286 с.

38. Сень Д.В. Казачество Дона и Северо-Западного Кавказа в отношениях с мусульманскими государствами Причерноморья (вторая половина XVII начало XVIII в.): монография. - Ростов н/Д, 2009. 280 с.

39. Соловьёв В.А. Екатеринодарская крепость. Краснодар, 2003. 40 с.

40. "Станиця" Атама́нь - виставковий етнотуристичний комплекс просто неба (понад 60 га), створений за ініціативою крайової адміністрації у серпні 2009 р. на околиці станиці Тамань Краснодарського краю на землі, що має важливе археологічне значення. Споруди комплексу є невдалою імітацією історичних i виконані з використанням сучасних технологій і матеріалів, криниці та мьохи позначені $и$ не надземною частиною.

41. Україна. Історичний атлас. 8 клас. / Концепція атласу та авторське опрацювання мап - Ю. Аоза. - К.: Мапа, 1998.

42. Україна. Історичний атлас. 9 клас. / Концепція атласу та авторське опрацювання мап - Ю. Аоза. Київ: Мапа, 1999.

43. Черноморские казаки / И.Д. Попко. Черноморские казаки в их гражданском и военном быту; П.П. Короменко. Черноморцы. М.: Вече, 2009.

44. [Шкуро В.И.] Динской (Донской), курень, ныне ст-ца Динская - р-ный центр Краснодарского края // Энциклопедический словарь по истории Кубани с древнейших времён до октября 1917 года. Краснодар, 1997.

45. Щербина Ф.А. История Кубанского казачьего войска. Т. І. Екатеринодар, 1910.

\section{References:}

1. Avramenko A.M., Vinogradov V.B., Kakusha O.N. (1997) Istoricheskaya geografiya Krasnodarskogo kraya i Adygei (dosovetskij period): Programma (chast 1) integrirovannogo fakultativnogo kursa dlya shkol, gimnazij i liceev. ArmavirKrasnodar [in Russian].

2. Avramenko A.M. (2001) Nereshyonnye problemy izucheniya administrativnoterritorialnogo deleniya Severnogo Kavkaza konca XVIII - nachala XX v. // 
Severnyj Kavkaz: geopolitika, istoriya, kultura. Materialy vserossijskoj nauchnoj konferencii (Stavropol, 11-14 sentyabrya 2001 g.). Ch. 1. Moskva - Stavropol [in Russian].

3. Avramenko A.M. (2002) Atlas istorii kazachestva: ideya, koncepciya i struktura // Kazachestvo Rossii: istoriya i sovremennost. Tezisy Mezhdunarodnoj nauchnoj konferencii g. Gelendzhik (8-11 oktyabrya 2002 g.). Krasnodar [in Russian].

4. Avramenko A.M. (2002) Podgotovka "Kubanskogo istoricheskogo atlasa": ideya i predpolagaemaya struktura // Osvoenie Kubani kazachestvom: Voprosy istorii i kultury. Krasnodar [in Russian].

5. Avramenko A.M. (2005) Istoriya Kubani v suchasnih ukrayinskih atlasah // Istorikogeografichni doslidzhennya v Ukrayini. Zbirka naukovih prac. Chislo 8. Kyiv [in Ukrainian].

6. Avramenko A.M. (2006) Chernomorskoe kazache vojsko po perepisi 1793-1794 gg. [Karta]. // Pervaya perepis kazakov-pereselencev na Kuban v konce XVIII veka:

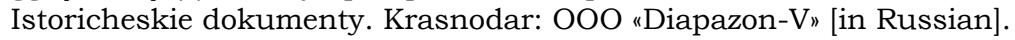

7. Avramenko A.M. (2007) Materialy Mezhevoj komissii Chernomorskogo kazachego vojska (1848-1860 gg.) kak istoriko-geograficheskij istochnik // Istoriko-geograficheskij sbornik. Vyp. 1. Krasnodar: OOO "Kartika" [in Russian].

8. Avramenko A. M. (2008) Tretya zbirka "Kuban - Ukrayina" i deyaki problemi kubanskoyi ukrayinistiki // Kuban-Ukraina: voprosy istoriko-kulturnogo vzaimodejstviya. Vyp. 3. Krasnodar [in Ukrainian].

9. Avramenko A. (2011) Kubanskoe kazache vojsko (po dannym na 1 noyabrya 2010 g.) [karta] // Enciklopediya kubanskogo kazachestva / Pod red. V.N. Ratushnyaka. Krasnodar: Tradiciya, 2011. Cvetnaya vklejka mezhdu [in Russian].

10. Avramenko A. Zmini v geografiyi naselenih punktiv Kubani, nazvi yakih pohodyat vid zaporozkih kureniv (do problemi zberezhennya istoriko-kulturnoyi spadshini) // Zapiski Naukovogo tovaristva imeni Shevchenka. T. CCLXHI: Praci Komisiyi specialnih (dopomizhnih) istorichnih disciplin. Lviv, 2018 [in Ukrainian].

11. Avramenko A.M. Koncepciya Kubanskogo istoriko-kulturnogo atlasa kak sostavnoj chasti programmy izucheniya kulturnogo naslediya narodov Severnogo Kavkaza [Elektronnyj resurs] // Nasledie vekov. 2018. № 1. URL: http://heritagemagazine.com/wp-content/uploads/2018/02/2018_1_Avramenko.pdf (data obrasheniya 24.10.2019). [in Russian].

12. Artyuhin Yu.V. Perestrojka beregovoj zony Azovskogo morya kak faktor nekotoryh istoricheskih sobytij XVIII-XX vv. // Istoriko-geograficheskij sbornik. Vol. 1. Krasnodar, 2007. [in Russian]

13. Artyuhin Yu.V., Rodionova N.B. Istoriko-geograficheskie aspekty osvoeniya Ejskogo limana Azovskogo morya i evolyucii naselyonnyh punktov ego poberezhya // Istorikogeograficheskij sbornik. Vol. 1. Krasnodar, 2007. [in Russian].

14. Artyuhin Yu.V. Okeanologicheskij fon protivoborstva Rossii i Turcii za obladanie ustevoj chastyu r. Don. // Bolshoj Rombit. Sbornik statej po istorii i istoricheskoj geografii Vostochnogo Priazovya. Ejsk, 2010. [in Russian].

15. Artyuhin Yu.V. Klimaticheskij i okeanologo-landshaftnyj fon protivoborstva kazachestva i Osmanskoj imperii v XVI-XVII vv. // Bosporskie issledovaniya. Vol. XXXII. 2016. [in Russian].

16. (2006) Atlas $z$ istoriyi Ukrayini (druga polovina XVIII - pochatok XX st.). 9 klas. / Uporyad.: O.V. Gisem, D.V. Isayev, O.O. Martinyuk. K.: IPT

17. (2012) Atlas istoriyi Ukrayini; upor. D. Isayev. K.: DNVP "Kartografiya".

18. Volkov I.V. Eshe raz ob Adahunskom srazhenii kazachego flota v 1638 g. // Drevnosti Kubani. Vyp. 16. Krasnodar, 2000. [in Russian]. 
19. Dnevniki Ivana Lazarevicha Polezhaeva (30-e gody, st-ca Umanskaya) // Rodnaya Kuban (literaturno-istoricheskij zhurnal). Krasnodar, 2002. № 3 [in Russian]

20. Enciklopediya istoriyi Ukrayini. T.3. E-J. K., 2005; T. 5. Kon - Kyu. K., 2008. 21. (2007) Istoriko-geograficheskij sbornik. Vol. 1. Krasnodar, 2007. 482 s., kart. [in Russian].

22. (1997) Istoriya Kubani. Krasnodarskij kraj. Respublika Adygeya. [Atlas]. M., Krasnodar. [in Russian].

23. Istoriya Kubani s drevnejshih vremyon do konca XX veka: Uchebnik dlya vysshih uchebnyh zavedenij. / Rukovoditel avt. kollektiva prof. V.E. Shetnyov. Krasnodar: OIPC "Perspektivy obrazovaniya", 2004. Cvetnaya karta-vklejka mezhdu [in Russian].

24. Korolev V.N. Adahunskoe srazhenie // Izvestiya vysshih uchebnyh zavedenij. SeveroKavkazskij region. Obshestv. nauki. Rostov-na-Donu, 1993. № 1/2 [in Russian].

25. Korolenko P.P. (1874) Chernomorcy. SPb. [in Russian].

26. Kulchickij S.V. Golodomor 19321933 rr. na Kubani // Kuban-Ukraina: voprosy istoriko-kulturnogo vzaimodejstviya. Vyp. 3. Krasnodar, 2008 [in Ukrainian].

27. Litvinskaya S.A. (1997) Istoricheskaya ekologiya (regionalnyj ocherk): Uchebnoe posobie. Krasnodar [in Russian].

28. (2000) Naselenie Rossii v XX v.: V 3 t. T. 1. Moskva [in Russian].

29. Ocherki istorii organov vnutrennih del Kubani. 1793-1917. / Pod red. professora V.N. Ratushnyaka. Krasnodar: EDVI, 2002. Kolorovi karti vklejki (avtor A. Avramenko): Administrativno-territorialnoe delenie i policiya Prikubanskih zemel v 1794-1860 gg.; Administrativno-policejskoe delenie Kubanskoj oblasti i Chernomorskogo okruga v 18701888 gg.; Administrativno-policejskoe delenie Kubanskoj oblasti i Chernomorskoj gubernii v 1888-1917 gg.

30. Popka I. (1858) Chernomorskie kozaki v ih grazhdanskom i voinskom bytu. Ocherki kraya, obshestva, vooruzhennoj sily i sluzhby. V 2-h ch. i 17 rasskazah. SPb.: Tipografiya P.A.Kulisha/ Vklejka v kinci knigi. [in Russian].

31. Popka I.D. Chernomorskie kazaki v ih grazhdanskom i voennom bytu: Ocherki kraya, obshestva, vooruzhennoj sily i sluzhby. V 2 ch. Krasnodar: Sov. Kuban, 1998. [in Russian].

32. Rakachyov V. N. Golod 1932-1933 gg. na Kubani i ego demograficheskie posledstviya // Kuban-Ukraina: voprosy istoriko-kulturnogo vzaimodejstviya. Vyp. 3. Krasnodar, 2008 [in Ukrainian].

33. Rossijskij gosudarstvennyj arhiv ekonomiki. F. 5675. Op. 1. D. 32. L. 26.

35. Samovtor S.V. (2008) Otrazhenie processov kazachej kolonizacii v toponimii Kubani (konec XVIII - nachalo XX vv.): Avtoreferat diss. ... kand. ist. nauk. Stavropol [in Russian].

36. Severnyj Kavkaz v sostave Rossijskoj imperii. M., 2007. 460 s., il., kart [in Russian].

37. Sen D.V. (2002) Vojsko Kubanskoe Ignatovo Kavkazskoen: istoricheskie puti kazakovnekrasovcev (1708 - konec 1920-h gg.). Krasnodar, 2001. 385 s.; To zhe. 2-e izd., ispr. i dop. Krasnodar [in Russian].

38. Sen D.V. (2009) Kazachestvo Dona i Severo-Zapadnogo Kavkaza v otnosheniyah s musulmanskimi gosudarstvami Prichernomorya (vtoraya polovina XVII - nachalo XVIII v.): monografiya. Rostov-na-Dony [in Russian].

39. Solovyov V.A. (2003) Ekaterinodarskaya krepost. Krasnodar [in Russian].

40. "Stanicya" Atamán - vistavkovij etnoturistichnij kompleks prosto neba (ponad 60 ga), stvorenij za iniciativoyu krajovoyi administraciyi u serpni 2009 r. na okolici stanici Taman Krasnodarskogo krayu na zemli, sho maye vazhlive arheologichne znachennya. Sporudi kompleksu ye nevdaloyu imitaciyeyu istorichnih i vikonani $z$ vikoristannyam suchasnih tehnologij i materialiv, krinici ta lohi poznacheni lishe nadzemnoyu chastinoyu. 
41. (1998) Ukrayina. Istorichnij atlas. 8 klas. / Koncepciya atlasu ta avtorske opracyuvannya map Yu. Loza. Kyiv: Mapa [in Ukrainian].

42. (1999) Ukrayina. Istorichnij atlas. 9 klas. / Koncepciya atlasu ta avtorske opracyuvannya map - Yu. Loza. Kyiv: Mapa [in Ukrainian].

43. Chernomorskie kazaki / I.D. Popko. Chernomorskie kazaki v ih grazhdanskom i voennom bytu; P.P. Korolenko. Chernomorcy. M.: Veche, 2009.

44. [Shkuro V.I.] Dinskoj (Donskoj), kuren, nyne st-ca Dinskaya - r-nyj centr Krasnodarskogo kraya // Enciklopedicheskij slovar po istorii Kubani s drevnejshih vremyon do oktyabrya 1917 goda. Krasnodar, 1997. [in Russian].

45. Sherbina F.A. (1910) Istoriya Kubanskogo kazachego vojska. T. I. Ekaterinodar [in Russian].

\author{
Анатолий Авраменко \\ ORCID: https://orcid.org/0000-0003-2538-7195 \\ кандидат исторических наук, доцент \\ руководитель научного центра \\ Краснодарской краевой общественной организации \\ "Содружество Кубань - Украина" \\ УА. КАубная, 12 корп. А, Краснодар, 350051, Россия \\ shron2011a@gmail.com
}

\title{
Историко-географические аспекты исследования прошлого иерноморского и кубанского казачества (вопросы картографической реконструкиии)
}

В статье исследуются географические аспекты истории черноморского и кубанского казачества и их отображения способами исторической картографии. Приведены примеры ошибок, происходяших од неумения исследователей использовать методы исторической географии и картографии. Обрашено внимание на ошибки некоторых украинских исторических атласов и российских публикаиий. Статья содержит образиы авторских карт, позволивших поднять на новый уровень изучения административно-территориального деления, географии и топографии населенных пунктов Кубани, Голодомора 1932-1933 годов и некоторых других проблем региональной истории.

Ключевые слова: историческая картография, историческая география, Кубань, Черноморское казачье войско, Кубанское казачье войско, историкокартографическая реконструкиия. 
Додатки:

Додаток 1. Чорноморське козацьке військо у 1793-1794 рр. (автор А. Авраменко)

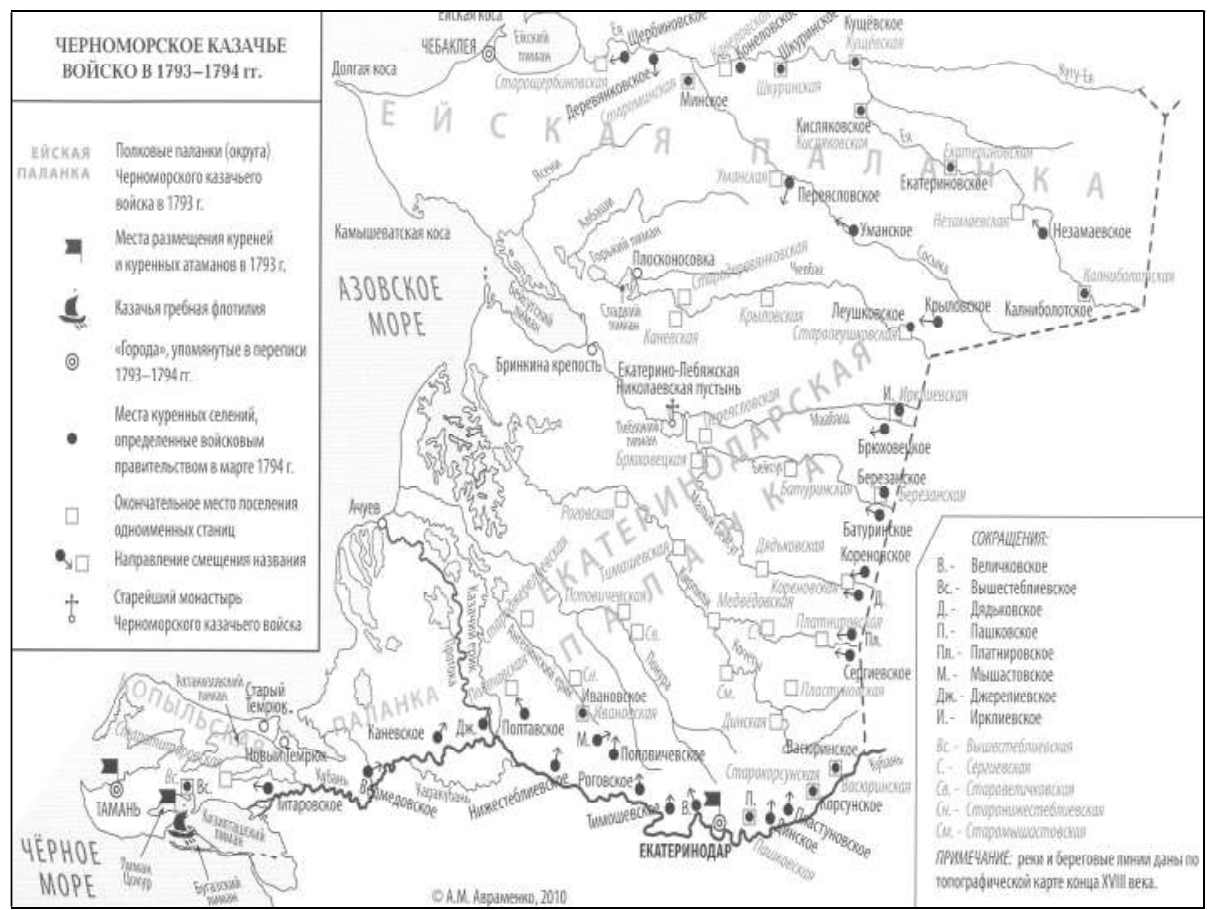


Додаток 2. Пцан фортеці у Єкатеринодарі. Автор В. Сомовйов

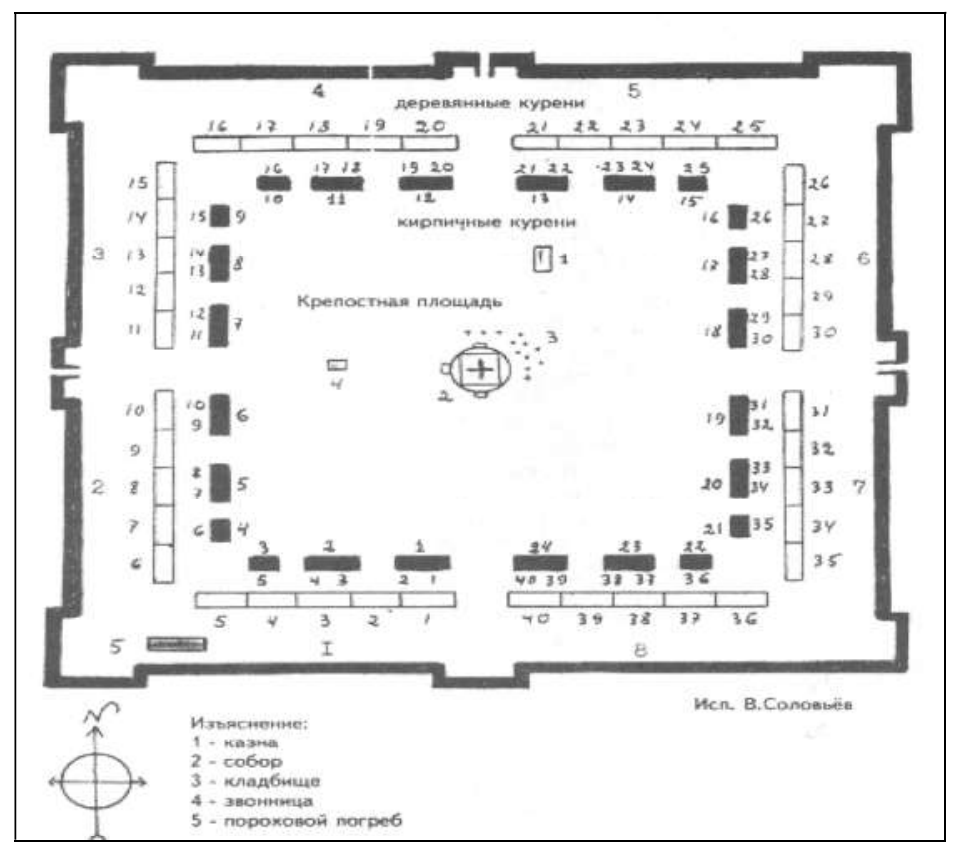

Додаток 3. Фото залишків фортеці у Краснодарі, зроблене німецьким цьотчиком. 1941 p.

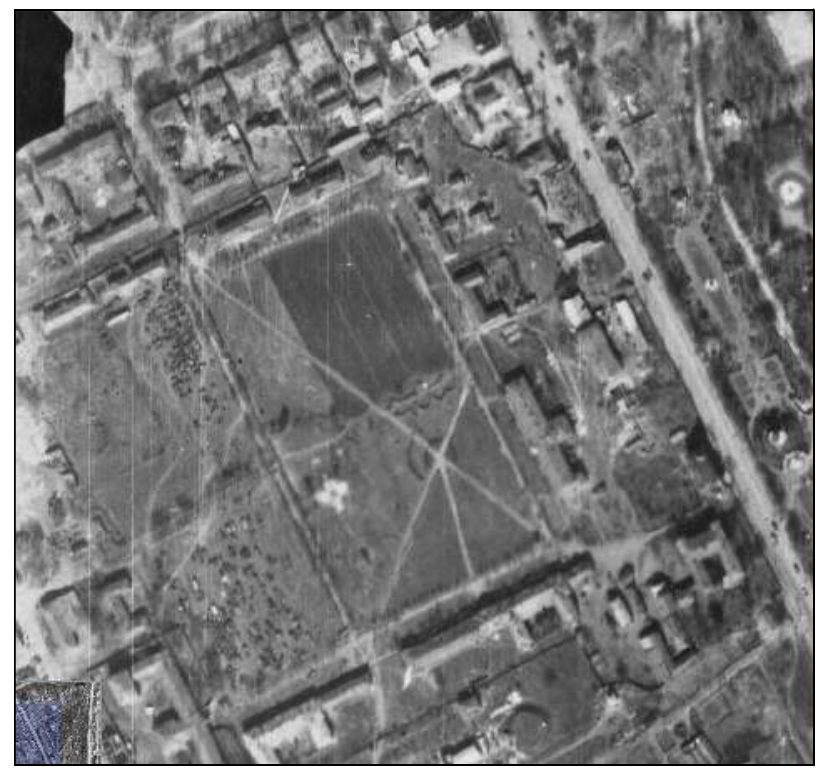


Додаток 4. Єкатеринодар у першій половині XIX ст. (автор А. Авраменко)

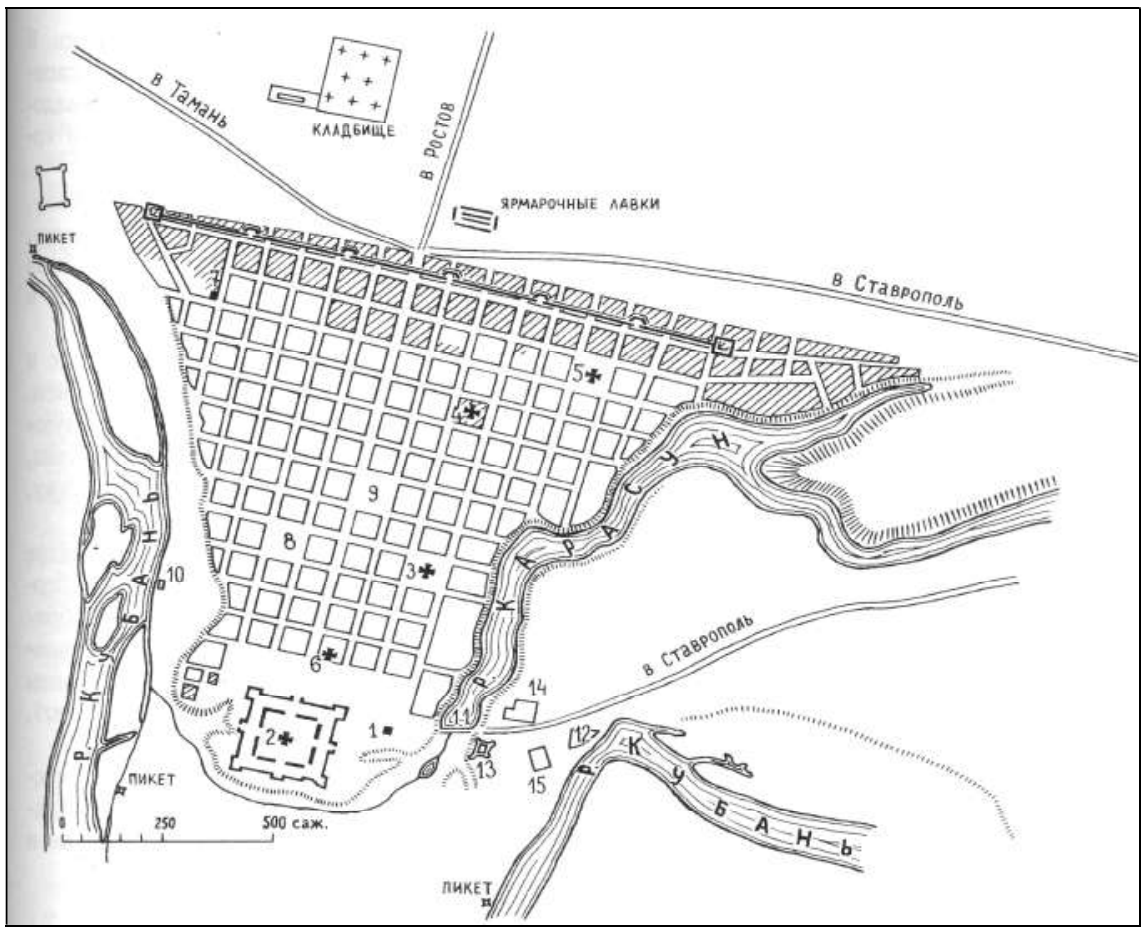

ir Вал Єкатеринодарської фортеці і курені (касарні)

тил Квартали, побудовані у 1819-1848 рр.

$\overline{7}=$ Північний вал з батареями (1818р.)

Церкви
Цифрами позначені:

1 Військове учимище

2 Воскресенська соборна церква

3 Церква св. Катерини

4 Церква св. Димитрія (1818р.)

5 Церква св. Димитрія (1848р.)

6 Вірменська церква

7 Богадікьня з церквою св. Іоанна

(1818 p.)

8 Старий ринок

Примітка: Береги рік показані на 1848 рік
Поштові шляхи

9 «Новоторгующий" ринок (1818р.)

10 Пристань дмя байдаків і човнів

(1818 р.)

11 Гребця

12 Міновий двір

13 Головний Єкатеринодарський пост

14 Поштова станція

15 Карантин 
Додаток 5. Адміністративний-територіальний поділ і поліція прикубанських земель у 1794-1860 рр. (автор А. Авраменко)

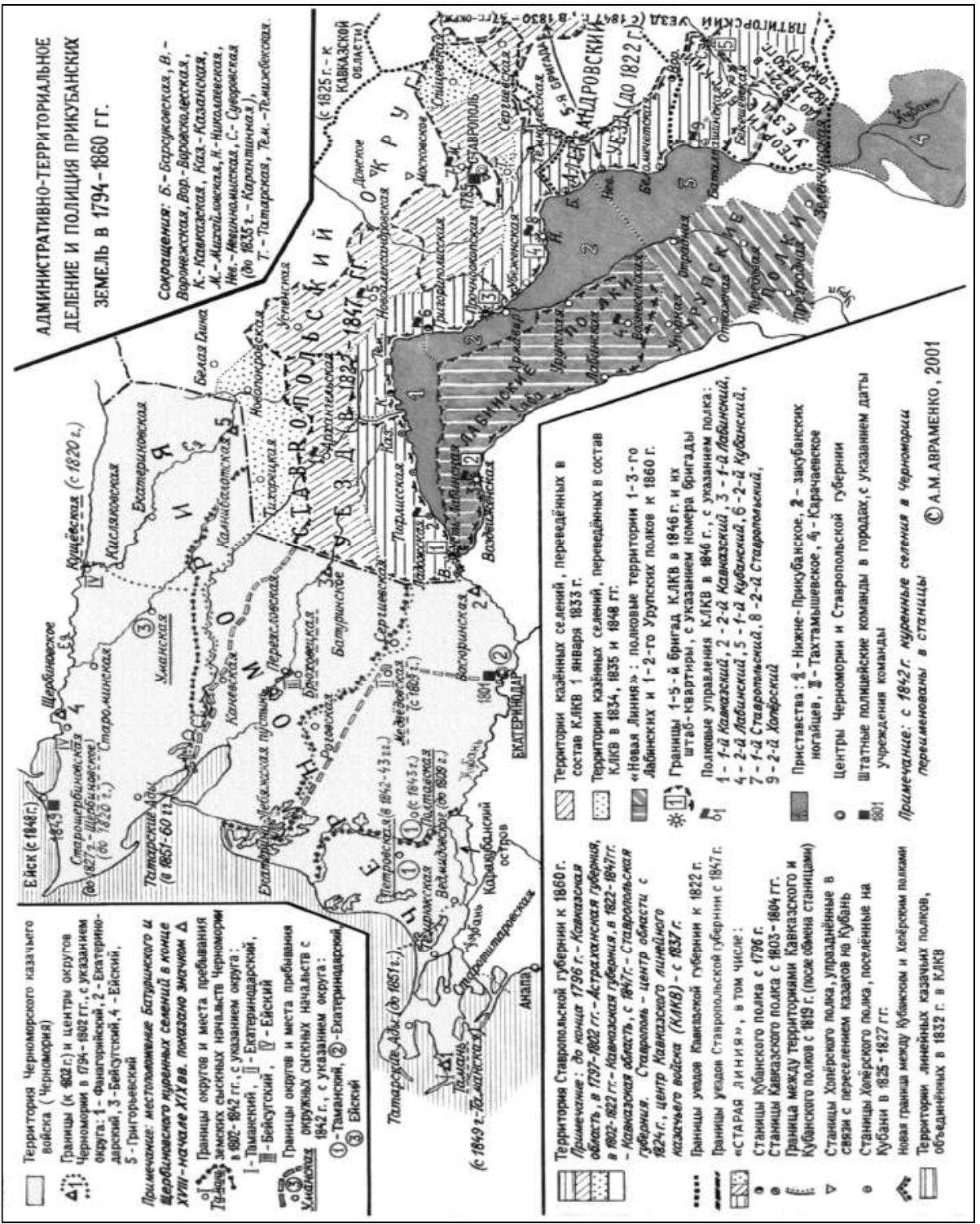


Додаток 6. Адміністративний-поліцейський поді^ Кубанської області i Чорноморського округу в 1870-1888 pp. (автор А. Авраменко)

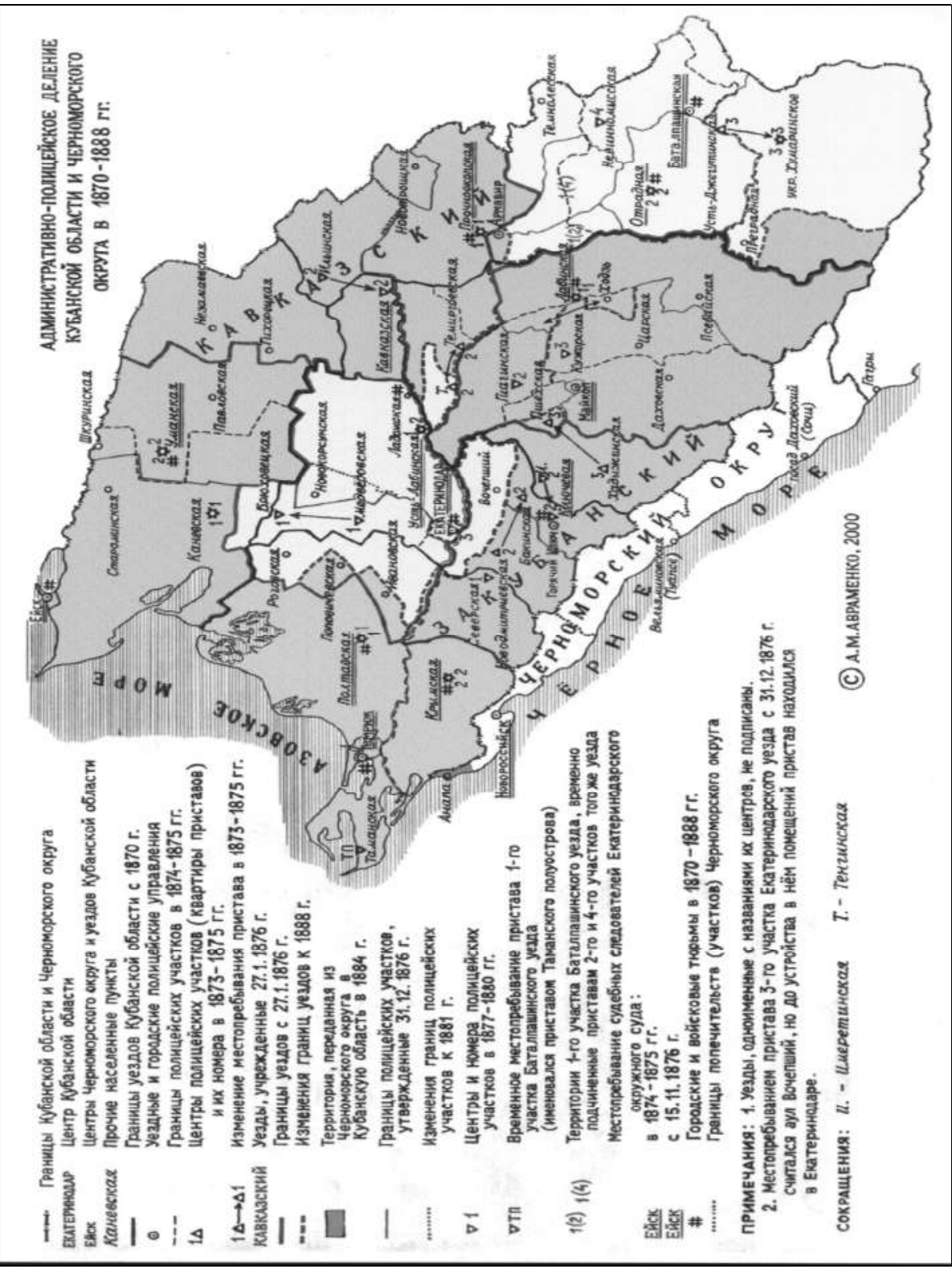


Додаток 7. Адміністративний-поліцейський поділ Кубанської області і Чорноморської губернії у 1888-1917 pp. (автор А. Авраменко)

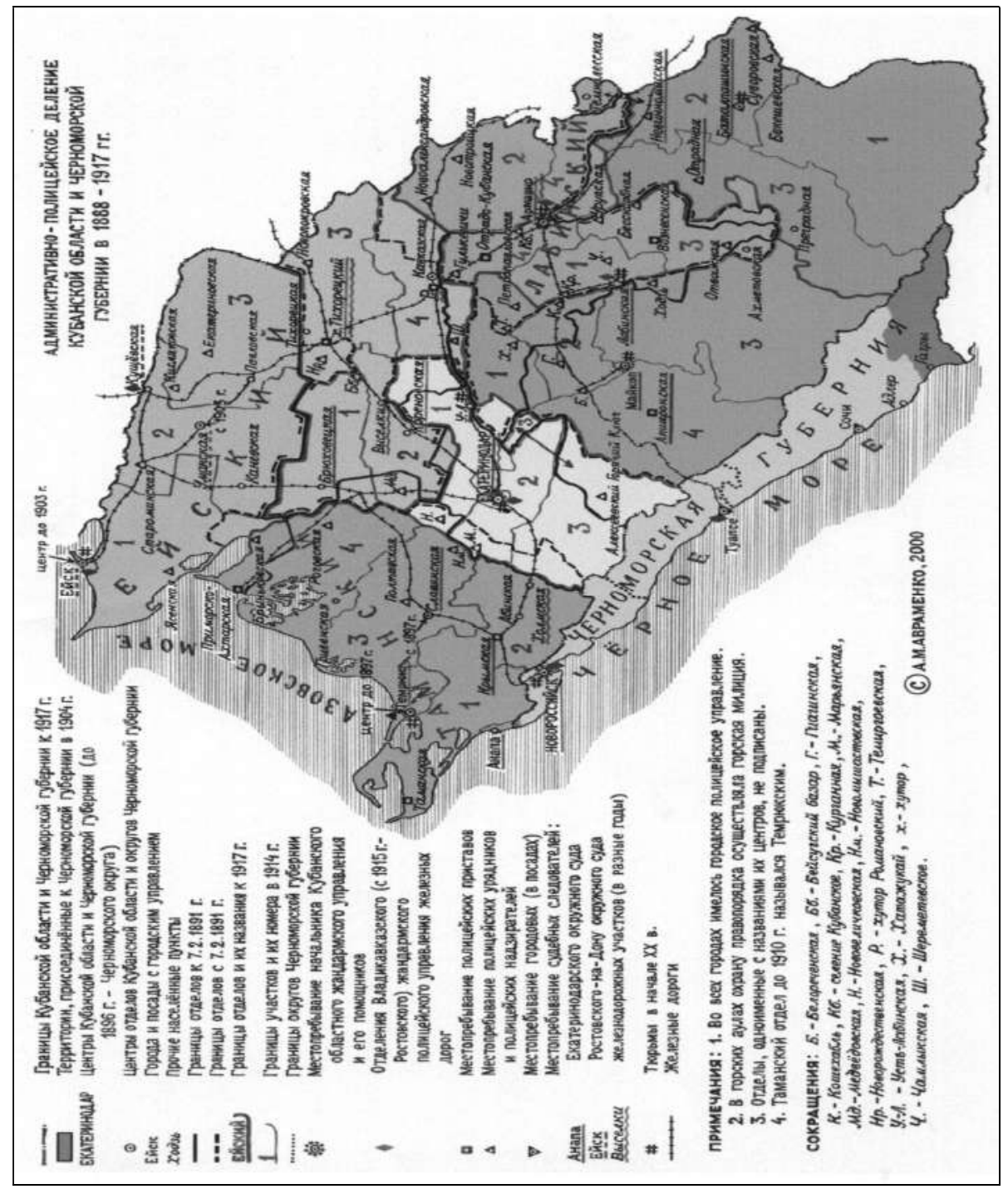

Отримано: 14.11.2019p. 